\title{
Factors influencing apical debris extrusion during endodontic treatment - A review of the literature
}

\author{
SADJ February 2021, Vol. 76 No. 1 p28 - p36
}

N Predin Djuric ${ }^{1}$, PJ van der Vyver ${ }^{2}$, M Vorster $^{3}$, ZI Vally ${ }^{4}$

\section{INTRODUCTION}

The primary cause of a periapical inflammatory lesion is intra-radicular microbial infection. ${ }^{1}$ Prevention and elimination of apical periodontitis is achieved through successful endodontic treatment. ${ }^{2}$ Endodontic treatment is designed to maintain and restore the health of the periapical tissues and prevent periapical disease. It may be defined as the combination of mechanical instrumentation of the root canal system with bactericidal irrigation and obturation with an inert material. ${ }^{3,4}$

Technically, the goal of instrumentation and irrigation is to debride and entirely remove infected tissue debris from the root canal system and create a uniform conical shape that allows medicament delivery and adequate obturation..$^{4,5}$ Microbiologically, the goal of instrumentation and irrigation is to eliminate micro-organisms, reduce their survival in the root canal system and neutralise any antigenic potential of the microbial components remaining in the canal. $4,6,7$

\section{Keywords}

Apical debris extrusion, canal preparation, glide path preparation, instrument design, irrigation, kinematics.

\section{Author affiliations:}

1. Natasa Predin Djuric: BDS, PG Dip Dent (Endo)(Pret), Department of Odontology, School of Dentistry, University of Pretoria, Pretoria, South Africa and Department of Dentistry, Cecilia Makiwane Hospital, Eastern Cape Department of Health, Eastern Cape, South Africa.

ORCID Number: 0000-0002-0993-856X

2. Peet J van der Vyver: BChD, PG Dip Dent (Endo), PG Dip Dent (Aesthet Dent), MSc, PhD (Pret), Department of Odontology, School of Dentistry, University of Pretoria, Pretoria, South Africa. ORCID Number: 0000-0003-1951-6042

3. Martin Vorster: BChD, PG Dip Dent (Endo), MSc (Pret), Department of Odontology, School of Dentistry, University of Pretoria, Pretoria, South Africa.

ORCID Number: 0000-0003-4470-1530

4. Zunaid I Vally: BDS, Mdent (Prosthodontics) (Wits), Department of Odontology, School of Dentistry, University of Pretoria, Pretoria, South Africa.

ORCID Number: 0000-0002-2718-4706

Corresponding author: Peet $\mathrm{J}$ van der Vyver

Department of Odontology, School of Dentistry, University of Pretoria, Gauteng, South Africa.

Email: peetv@iafrica.com

Author contributions:

1. Natasa Predin Djuric: Scientific writing - $50 \%$

2. Peet $\mathbf{J}$ van der Vyver: Scientific writing and proofreading of the manuscript - 20\%

3. Martin Vorster: Scientific writing and proofreading of the manuscript - $20 \%$

4. Zunaid I Vally: Final editing and proofreading of the manuscript $10 \%$

\section{Clinical relevance of debris extrusion}

During chemo-mechanical preparation, dentinal chips, pulpal fragments, necrotic debris, irrigants and microorganisms may be inadvertently disseminated from the root canal into periapical tissues, ${ }^{8}$ resulting in postoperative complications such as periapical inflammation, postoperative pain and delayed healing. ${ }^{9-10}$

The amount of material extruded through the apical foramen is one of the main concerns when using an instrumentation technique, ${ }^{11}$ as periapical extrusion of debris, dentine mud or microbes is thought to play a role in postoperative flare-ups and, even more importantly, in endodontic treatment failures. ${ }^{12-14}$ The frequency of these complications is reported to range between $1.4 \%$ and $16 \% .{ }^{10}$ Preventing debris extrusion therefore plays a significant role in the course of root canal treatment. ${ }^{15}$

All instrumentation techniques and files are associated with apical extrusion of debris (Figure 1); however, the amount of extruded debris may differ according to the preparation technique used. ${ }^{8,16,17}$ The design of rotary files and the chosen kinematics contributes to accumulating dentinal debris into the flutes of the preparation instruments and directing it coronally toward the canal orifice, lessening apical compaction of debris. ${ }^{18}$ Hence, a more favourable postoperative course can be obtained by choosing a technique that lessens apical debris extrusion. ${ }^{19,20}$ Nair et al. ${ }^{21}$ concluded that all instrumentation techniques produce apical extrusion of debris even when the preparation is maintained at the apical terminus.

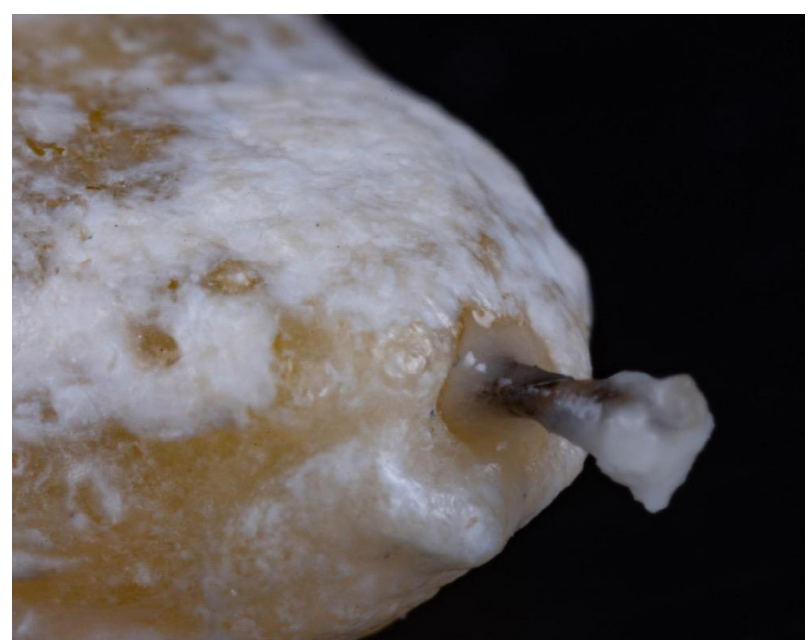

Figure 1. Extrusion of apical debris through root canal foramen during root canal preparation. 
Instrumentation techniques

\section{Manual techniques}

Ruiz-Hubard et al. ${ }^{22}$ compared conventional step-back instrumentation to crown-down technique in plastic blocks in both curved and straight canals. The authors found that less debris were apically extruded using the crown-down pressure less technique than with step-back instrumentation. McKendry ${ }^{23}$ found lesser amounts of apical debris extrusion after using a balanced forced technique, compared with step-back techniques. Similarly, Al-Omari and Dummer ${ }^{24}$ found that step-back instrumentation with circumferential filing resulted in the most apical extrusion, whereas crown-down and balanced force techniques formed the smallest amount of debris.

\section{Manual vs. rotary techniques}

A mutual finding in the aforementioned studies is that a push-pull canal enlargement action such as filing produces more apical debris than instrumentation techniques that incorporate a rotational force. This led to the hypothesis that engine-driven rotary instruments using the balanced force technique will produce less debris than hand-filing techniques, decreasing potential for periradicular tissue irritation and postoperative sequelae. ${ }^{25}$ To decrease the amount of apical extrusion of debris, Del Fabbro et al. ${ }^{26}$ recommend the use of nickel-titanium (NiTi) instrumentation for root canal therapy.

Similarly, numerous studies report that using K-files for root canal instrumentation results in more postoperative pain than does rotary system use. ${ }^{27-29}$ However, Çiçek et al. ${ }^{30}$ obtained differing results, concluding that the modified step-back technique produced less pain in a 48hour period than did rotational and reciprocal preparation techniques. Arias et al. ${ }^{27}$ found that although an increased incidence of postoperative pain is anticipated after manual root canal instrumentation, postoperative pain after rotary canal preparation is expected to last longer. Kashefinejad et al. ${ }^{28}$ observed a significant difference in postoperative pain when comparing Mtwo (VDW, Munich, Germany) rotary instrumentation to K-file hand instrumentation. In the rotary group, only $13.3 \%$ of patients required analgesics as opposed to $56.7 \%$ in the hand file group.

\section{Continuous vs. reciprocating single-file systems}

Previous studies on postoperative pain have reported inconsistent results from the use of continuous rotary systems and reciprocating systems. ${ }^{20,31-33}$ In analysing postoperative pain, three different studies opted for One Shape (Micro-Mega, Besancon, France) as the file of choice for the rotary single-file instrument group in comparison with different single-file reciprocating instruments. ${ }^{29,32,34}$ Among the three relevant articles, Jain et al. ${ }^{34}$ and Mollashahi et al. ${ }^{29}$ report that there was no significant difference in the intensity of postoperative pain between the rotary single-file groups and reciprocating single-file groups. In contrast, a study by Neelakantan and Sharma ${ }^{32}$ states that compared to the One Shape rotary group, the reciprocating single-file groups exhibited significantly lower postoperative pain intensity.

Single-file vs. multi-file systems
A meta-analysis conducted by Sun et al. ${ }^{35}$ compared a total of 12 studies on postoperative pain after treatment with engine-driven rotary and reciprocating instruments. The authors concluded that multiple rotary-file systems contributed to a lower incidence of postoperative pain than did reciprocating single-file systems.

A study by Robinson et al. ${ }^{36}$ found that multiple rotary-file systems yielded cleaner canals with less debris accumulation remaining within the root canal than did reciprocating files. Using micro-computed tomography (micro$\mathrm{CT}$ ), this study compared the 3D distribution, quantity, and density of remaining inorganic debris in the mesial roots of mandibular molars after instrumentation. An average of $19.5 \%$ debris remained in the canal after single-file reciprocating instrumentation compared to $10.6 \%$ with the multi-file rotary technique, showing that reciprocating motion leaves more debris within the canal.

\section{Relationship between bacterial extrusion and amount of debris}

A study using a multipurpose analytic approach compared the levels of apically extruded bacterial and hard-tissue debris and intracanal bacterial reduction after root canal preparation. Apical extrusion of bacteria occurred in 90\% for XP-endo Shaper (FKG Dentaire, La Chaux-de-Fonds, Switzerland) and 81\% for Reciproc (VDW).

Intracanal bacterial reduction was greater when using the XP-endo Shaper. Both reciprocating and continuous rotation techniques produced similar volumes of hard-tissue debris extrusion. Hard-tissue debris extrusion was less frequent than bacterial extrusion and no correlation was observed between the volume of extruded debris and counts of extruded bacteria. ${ }^{37}$

These contradictory findings justify the need for further investigation of widely used systems. ${ }^{11}$ Although all instrumentation techniques appear to force intracanal content through the apex into the periapical tissues, ${ }^{11}$ the amount of debris extrusion may differ according to preparation techniques, kinematics and the design of the rotary file systems. ${ }^{38-40}$ Since new instruments and techniques are saturating the market, evaluation of current practices is important.

\section{Rotary kinematics}

Three groups of instruments are available for root canal preparation: manually operated instruments, engine-driven rotary instruments and engine-driven reciprocating instruments. ${ }^{41}$ The majority of commercially available rotary $\mathrm{NiTi}$ root canal systems are primarily driven in a continuous $360^{\circ}$ rotation motion around a single axis (Figure 2). ${ }_{4}^{42,43}$ Conventional continuous rotation has an increased risk of $\mathrm{NiTi}$ instrument fracture caused by torsional and flexural stresses. $^{44,45}$

Torsional fatigue is the twisting of a metal shaft around its longitudinal axis at one terminus, while the other file terminus is static (Figure 3). ${ }^{44}$ Torsional fracture occurs when a tip or any other part of the instrument binds and locks to the root canal walls, while the rest of the 
file continues in rotary motion. Hence it is possible for a practitioner to lessen the intensity of torsional stress by reducing apical force during canal instrumentation. Shaping root canals of smaller diameter generates more torsional stress than shaping larger diameter canals. ${ }^{46}$
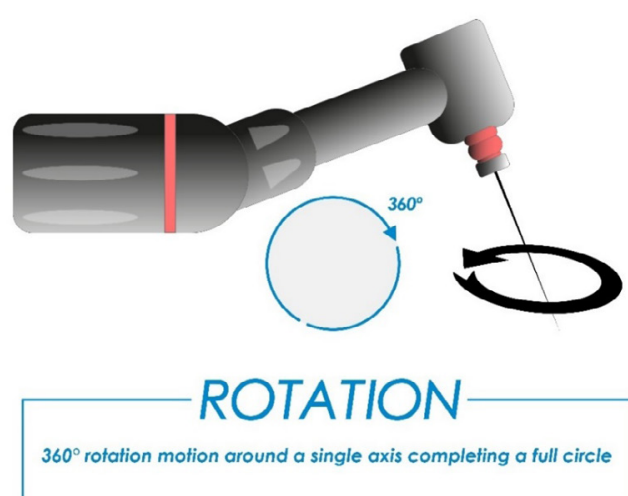

Figure 2. Engine-driven continuous rotation.

Cyclic fatigue ensues when a metal is subjected to recurrent cycles of tension and compression, causing its structure to deteriorate (Figure 4). ${ }^{44}$ Fracture due to flexural fatigue occurs when an instrument that has previously been weakened by metal fatigue is placed under further stress. The instrument does not bind to the root canal walls, but rotates freely until it fractures at the point of maximum flexure. ${ }^{46-48}$

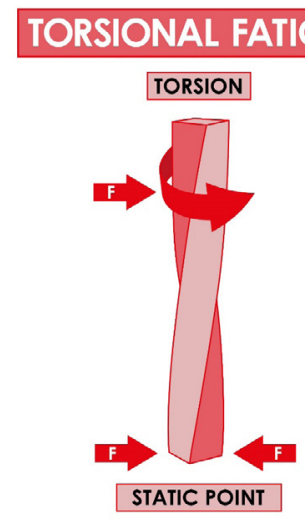

Fig. 3

Figure 3. Schematic presentation of forces contributing to torsional fatigue.

Figure 4. Schematic presentation of forces resulting in material cyclic fatigue.

Cyclic fatigue is most likely to occur in a canal with a severe curve and a short radius of curvature, ${ }^{44,49}$ whereas torsional stress might develop in straight canals. ${ }^{50}$ Cyclic fatigue is considered to be the principal cause of $\mathrm{NiTi}$ instrument separation. ${ }^{51}$

Increasing resistance to file separation has been the main goal of manufacturers in developing the latest NiTi rotary instruments, aimed at improving safety by means of pioneering design and manufacturing processes. ${ }^{52,53}$ To overcome the breakage of endodontic instruments caused by flexural fatigue, reciprocating movement was introduced. ${ }^{54}$ Recent literature data confirms that reciprocating motion can extend the cyclic fatigue resistance of NiTi instruments for longer than continuous rotation. ${ }^{54-56}$
Reciprocation, defined as any repetitive back-and-forth (up and down or forward and reverse) movement, was originally introduced in endodontics in 1958. ${ }^{42,43}$ Early reciprocating systems used an equal alternating motion of $90^{\circ}$ angles and in more recent systems of $30^{\circ}$ angles, none of which would complete a full rotation cycle. ${ }^{43}$ Over time, smaller yet still equal angles of clockwise (CW) and counter-clockwise (CCW) motion were used in M4 hand pieces (SybronEndo, California, USA), Endo-Eze AET (Ultradent, Utah, USA) and Endo-Express (Essential Dental Systems, New Jersey, USA) systems. ${ }^{42}$

Most recent developments contributed to the introduction of systems based on a new mode of mechanical rotation, a multiple reciprocation motion completing a $360^{\circ}$ cycle (Figure 5). In 2010, VDW launched Reciproc and in 2011 Dentsply Sirona launched WaveOne (Dentsply Sirona, Ballaigues, Switzerland), both of which are indicated for use as single-file techniques in automated reciprocation. ${ }^{43}$

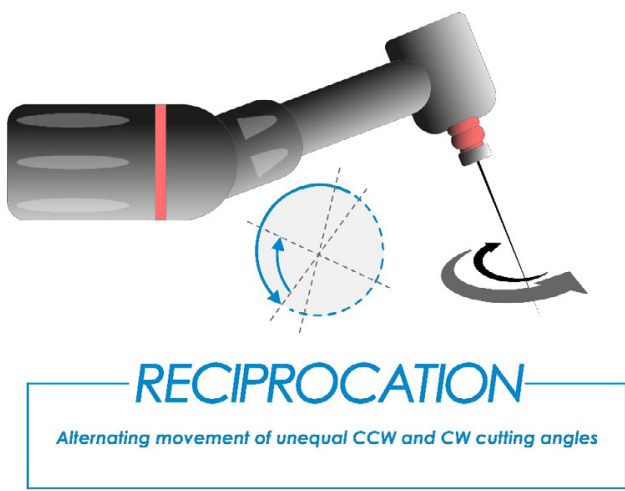

Figure 5. Engine-driven reciprocation.

The kinematics of reciprocating instrumentation is complex. Contrary to continuous rotary motion, the files rotate in a reverse balanced force turning back and forth. ${ }^{57,58}$

Reciprocating file systems use the alternating movement of unequal $\mathrm{CW}$ and $\mathrm{CCW}$ cutting angles (different to full sequence continuous rotation files) to prevent torsional fracture. Reciprocating movement aims to reduce this risk by engaging the file in a cutting motion, and then immediately disengaging it in a non-cutting motion. ${ }^{59}$

Reciprocating files currently available on the market are single-file systems designed to have a greater engaging CCW angle (left-cutting) than the disengaging CW angle (non-cutting). ${ }^{60}$ The CCW rotation advances the instrument apically as the dentine of the root canal wall is engaged and cut. This action is followed by a reduced angle $\mathrm{CW}$ rotation, which ensures that the instrument disengages before excessive torsional stress is transferred onto the metal alloy, preventing the instrument from binding onto the root canal walls. ${ }^{58}$

A number of studies have compared apical debris extrusion of continuous rotation systems with reciprocating systems. Multiple authors report that reciprocating files extruded more apical debris than rotary files. ${ }^{61-64}$ In contrast, numerous authors found that reciprocating instruments produced less apical debris extrusion than rotary instrumentation. ${ }^{65-68}$ Various studies also showed no significant difference between the two systems. ${ }^{69-72}$ 
A recent study investigated the amount of apically extruded debris created by the reciprocating file Reciproc blue (VDW) versus continuous rotation files HyFlex EDM (Coltene, Altstätten, Switzerland) and XP-endo Shaper (FKG Dentaire) during root canal preparation at body temperature. The XP-endo Shaper group extruded a significantly smaller amount of debris than Reciproc blue, whereas no significant difference was registered between the HyFlex EDM files and the other NiTi files tested. ${ }^{73}$ The reasons for the conflicting results could be variability in file design, the number of files used and the canal anatomy differences between the studies. ${ }^{74}$

\section{Apical patency}

Throughout canal instrumentation, both pulpal and dentinal debris can block the apical portion of the root canal and lead to procedural errors. ${ }^{24}$ A recognised practice for avoiding the accumulation of apical debris is maintaining apical patency, thereby preserving an open pathway between the apical orifice and the periodontal ligament. ${ }^{75}$

Establishing apical patency is the initial step in root canal treatment. The patency file ought to be used prior to irrigation to loosen compacted tissue remnants. ${ }^{76}$ Apical patency is defined as the ability to easily and reproducibly place a small hand file through the minor constriction of the apical foramen. It is followed by glide path preparation, after which root canal enlargement commences. ${ }^{77,78}$ Apical patency is maintained by repetitive recapitulation through the apical constriction with a small K-file with the aim of keeping the root canal free of debris. ${ }^{79}$

Lambrianidis et al. ${ }^{80}$ assessed the role of apical constriction on periapical extrusion of debris/material. They concluded that an enlarged apical constriction resulted in less material being extruded through the foramen. In con trast to this finding, a study by Tinaz et al. ${ }^{39}$ showed an increase in the amount of apically extruded material with an increase in the diameter of the apical patency. The conflicting findings can be attributed to the study design. In the study by Lambrianidis et al. ${ }^{80}$ the canal instrumentation was executed in two stages using a step-back technique. The root canals were initially only instrumented up to the apical constriction. In the second phase of canal preparation, the apical constriction was intentionally enlarged. The canals were already enlarged in phase one and this could have allowed easier elimination of debris, as the coronal portion of the canal space was wider in phase two.

A patency file should be used with care, because it may force accumulated debris apically with the risk of inoculating microbes into the periapical region. ${ }^{81}$ However, newly available evidence indicates that maintaining apical patency does not increase postoperative pain or the rate of postoperative flare-ups. ${ }^{82}$

\section{Glide path}

Glide path preparation is an adjunctive preliminary procedure prior to canal instrumentation. ${ }^{78}$ Although there is no current consensus on the definition of a glide path, ${ }^{83}$ it is commonly described as "a smooth radicular tunnel from the canal orifice to the physiologic terminus (apical foraminal constriction)". ${ }^{84}$ Before canal preparation, a reproducible glide path should be created to minimise procedural accidents and improve the shaping ability of the final canal shaping system. ${ }^{2,85}$ Initial glide path creation assists in minimising preparation times and preserves the original anatomy with little modifications and aberrations to the root canal curvature, ${ }^{83}$ improving the outcome of endodontic treatment. ${ }^{78}$

Manual and rotary glide path instruments are the first files to negotiate narrow and calcified root canal systems, hence they encounter high levels of torsional stress. ${ }^{44}$ If the instrument tip cross-section is larger than the canal width, instrument blades can bind into the root canal walls. This is known as taper locking. Creating a glide path decreases the contact area between the shaping file and root canal walls, reducing the likelihood of taper locking and subsequently decreasing torsional stress. ${ }^{86}$

The creation of a glide path has been recognised as crucially important in reducing the incidence of instrument fracture due to reduced torsional and flexural stress on the root canal instrument. ${ }^{87}$ Glide path preparation increases the efficacy of root canal preparation, as it produces a reproducible tunnel in which rotary preparation instruments can run smoothly with reduced incidences of instrument fracture or canal aberrations..$^{83,87-89}$

One of the risks of any instrumentation technique is apical debris extrusion, which increases the possibility of postoperative inflammatory reaction. ${ }^{90}$ Post-treatment complications are decreased because much of the pulp, bacteria and related irritants are removed during preenlargement procedures. Passing files through underprepared canals coronally pushes more irritants beyond the apex and generates more postoperative exacerbations. On the other hand, passing files through a cleaned preenlarged preparation equates to less debris being unintentionally inoculated periapically. ${ }^{25}$

Topçuoglu et al. ${ }^{91}$ demonstrated that creating a glide path prior to canal instrumentation reduced the amount of apically extruded debris during canal preparation in curved canals. More recently, Gunes and Yeter ${ }^{92}$ found that glide path preparation before root canal preparation with a Primary WaveOne Gold file (Dentsply Sirona) had no effect on apical debris extrusion.

The study compared the amount of apically extruded debris after using multiple glide path files, before preparing curved root canals with the reciprocating Primary WaveOne Gold single file. They found that K-files showed a significantly higher amount of debris extrusion than One $\mathrm{G}$ glide path files (Micro-Mega), which could be explained by the fact that the tip diameter of One $G$ files $(0.14 \mathrm{~mm})$ is smaller than the other glide path files used in the study.

However, there was no significant difference between the $\mathrm{K}$-files and the other rotary glide path files in terms of apical debris extrusion. ${ }^{92}$ These results could correlate with the finding of Tinaz et al. ${ }^{39}$ that the quantity of apically extruded debris increased in teeth with a greater apical patency during both manual instrumentation with $\mathrm{K}$-files and engine-driven rotary instrumentation with ProFile .04 Taper Series 29 (Dentsply Sirona). Regardless of 
the techniques used, there was a tendency for greater apical debris extrusion as the diameter of apical patency increased.

More debris is generally extruded during the main shaping procedure, than during the glide path preparation procedure. However in the latter, although the amount of debris may be small, this initially extruded debris may contain higher toxicity than debris extruded later by the shaping instrument. ${ }^{11}$

\section{Instrument design}

The objective of biomechanical preparation is to remove vital and necrotic pulp tissue, infected radicular dentine, micro-organisms and microbial toxins from the root canal system. ${ }^{93}$ Most current mechanical root canal instrumentation systems propose single- or multiple-file systems to prepare root canals to a minimal dimension. ${ }^{94}$ The standard enlargement of the root canal is typically associated with an ISO tip size of 25 and either a variable taper or a continuous $6 \%$ taper. $^{5,95}$

It is important to note that the design of rotary files and the selected motion contribute to collecting dentinal debris in the flutes of the instruments and directing it coronally toward the canal orifice, lessening the compaction of debris in the root canal. ${ }^{18}$ Inconsistency has been noted between different mechanical systems in terms of debris extrusion. ${ }^{40}$ Apical debris extrusion variability is presumed to be caused by differences in cross-section and cutting blade design, taper, tip type, configuration, concepts of use, flexibility, alloy, number of files used, kinematics, and cutting efficacy. ${ }^{96}$

In search of superior NiTi alloy properties, manufacturers have used new manufacturing methods, postproduction material heat treatments and different cross-sectional designs. NiTi alloys used for endodontic files can be grouped into instruments that primarily comprise the austenite structural phase (conventional NiTi, M-Wire, R-Phase) and those predominantly comprising the martensite structural phase (CM Wire, Gold and Blue heattreated $\mathrm{NiTi}){ }^{97}$

Heat-treated NiTi alloys include M-Wire, R-Phase and CM-Wire. M-wire has three crystalline phases: deformed and micro-twinned martensite, R-Phase, and austenite. M-Wire and R-Phase instruments show greater resistance to cyclic fatigue and superior flexibility than conventional NiTi files. CM-Wire uses the stable martensite phase because the austenite finishing temperature is above working temperature. CM-Wire reverts to its original shape after heat application or autoclaving. ${ }^{98}$

Currently available rotary NiTi file endodontic systems cater for both continuous rotation and reciprocating motion. The most widely used continuous rotation systems are ProTaper Universal (Dentsply Sirona), ProTaper Next (Dentsply Sirona), Revo-S (Micro-Mega), One Shape (Micro-Mega), One Curve (Micro-Mega), HyFlex CM (Coltene), HyFlex EDM (Coltene) and TruNatomy (Dentsply Sirona). WaveOne (Dentsply Sirona), WaveOne Gold (Dentsply Sirona), Reciproc (VDW) and Reciproc blue (VDW) are the main endodontic file brands that are used in reciprocation. ${ }^{99}$

\section{Clockwise/forward/right-cutting reciprocation}

Reciprocating motion is an evolution of the balanced force technique offering an alternative method to prevent procedural errors during root canal instrumenation. ${ }^{100}$ In theory, the alternating changes in the direction of rotation reduce the number of cycles of the instrument and therefore the cyclic fatigue on the instrument compared with that imposed when instruments are used in a consistent rotating motion. ${ }^{55,101}$ Based on several studies, root canal shaping with reciprocating motion has been postulated to offer superior fracture resistance..$^{54,101-104}$

Paqué ${ }^{105}$ demonstrated that the F2 ProTaper Universal in reciprocating motion is as efficient as the conventional ProTaper Universal full sequence (Dentsply Sirona) technique in continuous motion. A study by Espir ${ }^{106}$ produced comparable results, showing that $\mathrm{CW}$ reciprocation motion with Mtwo (VDW) results in effective canal preparation.

All continuous rotation systems are designed to cut in a $\mathrm{CW}$ direction (right-cutting). The rotary $\mathrm{CW}$ cutting instrument may neither cut nor infiltrate the canal walls if used in CCW reciprocating motion. Since the reciprocating file systems have been designed to cut in a CCW direction (left-cutting), the CCW angle of motion is greater that the $\mathrm{CW}$ angle. ${ }^{107}$ Reciprocating motion with $\mathrm{CW}$ rotation greater than the CCW motion could allow the use of a larger number of conventional rotary file systems, as the flutes of the majority of systems are designed for continuous CW rotation. ${ }^{106}$

In 2016, two studies evaluated the effects of kinematics on apical debris extrusion. These studies assessed the same instruments, used in the same sequence. Movement kinematics was the only variable between different groups, therefore excluding other variables such as the instrumentation sequence, instrument alloy and instrument design. The authors concluded that movement kinematics significantly affected the amount of apically extruded debris. ${ }^{108,109}$ Karatas et al. ${ }^{108}$ evaluated the influence of different movement kinematics (TF Adaptive motion, $90^{\circ} \mathrm{CW}-30^{\circ} \mathrm{CCW}$, $150^{\circ} \mathrm{CW}-30^{\circ} \mathrm{CCW}$ and continuous rotation) on apical debris extrusion using Twisted File Adaptive instruments (SybronEndo). According to their findings, when the reciprocation range increased apical debris extrusion decreased.

The decreased reciprocation range in the $90^{\circ} \mathrm{CW}-30^{\circ}$ $\mathrm{CCW}$ group produced more debris extrusion. The increased reciprocation range in the $150^{\circ} \mathrm{CW}-30^{\circ} \mathrm{CCW}$ group could have generated less extrusion because more debris was transported coronally by the file acting as a screw conveyor due to the enlarged reciprocation range. Arslan et al. ${ }^{109}$ measured the amount of apically extruded debris using Reciproc (VDW) instruments with various kinematics $\left(150^{\circ} \mathrm{CCW}-30^{\circ} \mathrm{CW}, 270^{\circ} \mathrm{CCW}-30^{\circ} \mathrm{CW}, 360^{\circ}\right.$ $\mathrm{CCW}-30^{\circ} \mathrm{CW}$ and continuous rotation). The results of their study revealed that the $150^{\circ} \mathrm{CCW}-30^{\circ} \mathrm{CW}$ and $270^{\circ} \mathrm{CCW}-30^{\circ} \mathrm{CW}$ reciprocating motions extruded significantly less debris than continuous rotation.

\section{Solutions and debris extrusion}

Irrigation is an essential part of the debridement sequence. Both dentine debris and the smear layer adhering to 
the canal walls are created by the engagement of endodontic instruments during preparation, ${ }^{110}$ and should be eliminated from the root canal system to improve outcome prognosis. Although debris and smear layer removal is primarily achieved by irrigation, ${ }^{111}$ approximately half of the debris created during instrumentation cannot be removed from the canal system. ${ }^{110}$

Irrigant infiltration of the apical portion of the canal is essential in order to clean and keep it free of debris, ${ }^{82}$ reducing the risk of blockages and apical debris extrusion. ${ }^{9}$ Irrigants often do not reach the apical third of the canal due to the vapour lock effect. An effective hydrodynamic effect can be produced by agitating the irrigant and significantly improving the exchange and efficiency of any desired solution. ${ }^{112}$

In a recent study by Gupta et al. ${ }^{113}$ different irrigation agitation techniques showed apical extrusion of both debris and irrigant. The mean amounts of apically extruded irrigant and debris were greater in agitation groups than in the no-agitation control groups. This could be due to greater turbulence caused within the canal as a result of improved irrigant displacement.

Elimination of dentine and pulpal debris is thought to be improved with frequent and abundant irrigation. ${ }^{114}$ Debatable results were found when investigating the relationship between the amount of apically extruded debris and irrigant use. Hinrichs et al. ${ }^{115}$ and Ferraz et al. ${ }^{116}$ found a positive correlation, while Myers and Montgomery ${ }^{117}$ and Tinaz et al. ${ }^{39}$ reported no correlation.

Sodium hypochlorite $(\mathrm{NaOCl})$ solution has the ability to dissolve organic material, ${ }^{118}$ hence displaying great potential to remove the debris produced during chemomechanical root canal preparation. ${ }^{119}$ It also exhibits antimicrobial properties, leading to successful decontamination of the root canal system. ${ }^{120}$ Although highly cytotoxic to the periapical tissues in high concentrations, ${ }^{76}$ it is the most widely used irrigant in endodontic treatment. ${ }^{121}$

In addition to dentinal debris collection within the root canal, endodontic instrumentation techniques produce a smear layer that accumulates on the root canal walls and blocks the openings of dentinal tubules. The smear layer consists of organic and inorganic substances including dentinal filings, fragments of odontoblastic processes and micro-organisms. ${ }^{122}$

Ethylenediaminetetraacetic acid (EDTA) is a chelating agent used as a final irrigant to remove the potentially infected smear layer and open calcified canals due to its decalcifying properties. Although NiTi instrument manufacturers recommend using EDTA preparations for lubrication during canal instrumentation, contact between EDTA and the periapical tissue cannot be excluded.123

A study by Cruz et al. ${ }^{124}$ investigated whether the use of a paste containing EDTA during cleaning and shaping of the root canal helped to eliminate debris. In the first group, $\mathrm{NaOCl}$ was used during canal preparation and final irrigation was achieved with $17 \%$ liquid EDTA. In the second group, $\mathrm{NaOCl}$ was also employed as the irrigating solution, but Glyde Root Canal Conditioner (Dentsply Sirona) was used with every instrument. Likewise, final irrigation was performed with $17 \%$ liquid EDTA. The authors concluded that the use of Glyde Root Canal Conditioner (Dentsply Sirona) during mechanical instrumentation resulted in increased accumulation of debris in the apical third of the root canals.

De Deus et al. ${ }^{125}$ took high-resolution 3D micro-CT scans of teeth to register and quantify the amount of accumulated hard-tissue debris within the root canal system following canal instrumentation. Hard-tissue debris occupied $34.6 \%$ of the canal volume when no irrigant was used during canal preparation. Irrigation with bidistilled water resulted in $16 \%$ volume of debris, while irrigation with $\mathrm{NaOCl}$ followed by EDTA resulted in $11.3 \%$ volume of debris remaining within the root canal system. Markedly more debris accumulated in the non-irrigated specimen, undoubtedly due to the lack of liquid flow.

\section{CONCLUSION}

Apart from instrumentation techniques, instrument design and irrigation methods, kinematics plays an important role in apical extrusion of debris and should be viewed as a key factor in the complex aetiology of debris extrusion. Careful selection of endodontic instruments and the utilization of alternative rotary kinematics in a clinical setting might aid in the reduction of debris extrusion and subsequently limit irritation to peripapical tissue.

\section{References}

1. Möller AJR, Fabricius L, Dahlén G, Öhman AE, et al. Influence on periapical tissues of indigenous oral bacteria and necrotic pulp tissue in monkeys. Eur J Oral Sci. 1981; 89(6): 475-84.

2. Berutti $E$, Negro AR, Lendini M, Pasqualini D. Influence of manual preflaring and torque on the failure rate of ProTaper rotary instruments. J Endod. 2004; 30(4): 228.

3. Ng YL, Mann V, Rahbaran S, Lewsey J, et al. Outcome of primary root canal treatment: systematic review of the literature - Part 2. Influence of clinical factors. Int Endod J. 2008; 41(1): 6-31.

4. Haapasalo M, Endal U, Zandi H, Coil JM. Eradication of endodontic infection by instrumentation and irrigation solutions. Endod Topics. 2005; 10(1): 77-102.

5. Peters OA. Current challenges and concepts in the preparation of root canal systems: A review. J Endod. 2004; 30(8): 559-67.

6. Riitano F. Anatomic Endodontic Technology (AET) - a crowndown root canal preparation technique: basic concepts, operative procedure and instruments. Int Endod J. 2005; 38(8): 575-87.

7. Wang J, Jiang Y, Chen W, Zhu C, et al. Bacterial flora and extraradicular biofilm associated with the apical segment of teeth with post-treatment apical periodontitis. J Endod. 2012; 38(7): 954-9.

8. Kustarcı A, Akpınar KE, Er K. Apical extrusion of intracanal debris and irrigant following use of various instrumentation techniques. Oral Surg, Oral Med, Oral Pathol, Oral Radiol, Endodontol. 2008; 105(2): 257-62.

9. Siqueira JF. Microbial causes of endodontic flare-ups. Int E ndod J. 2003; 36(7): 453-63.

10. Siqueira JF, Jr., Rôças IN, Favieri A, Machado AG, et al. Incidence of postoperative pain after intracanal procedures based on an antimicrobial strategy. J Endod. 2002; 28(6): 457-60.

11. Tanalp J, Güngör T. Apical extrusion of debris: a literature review of an inherent occurrence during root canal treatment. Int Endod J. 2014; 47(3): 211-21. 
12. Yusuf $\mathrm{H}$. The significance of the presence of foreign material periapically as a cause of failure of root treatment. Oral Surg Oral Med Oral Pathol. 1982; 54(5): 566-74.

13. Sjogren U, Hagglund B, Sundqvist G, Wing K. Factors affecting the long-term results of endodontic treatment. J Endod. 1990; 16(10): 498-504.

14. Siqueira JF. Aetiology of root canal treatment failure: why welltreated teeth can fail. Int Endod J. 2001; 34(1): 1-10.

15. Torabinejad M, Walton RE. Managing endodontic emergencies. J Am Dent Assoc (1939). 1991; 122(5): 99,101,3

16. Bürklein S, Schäfer E. Apically extruded debris with reciprocating single-file and full-sequence rotary instrumentation systems. J Endod. 2012; 38(6): 850-2.

17. Kirchhoff AL, Fariniuk LF, Mello I. Apical extrusion of debris in flat-oval root canals after using different instrumentation systems. J Endod. 2015; 41(2): 237-41.

18. Beeson TJ, Hartwell GR, Thornton JD, Gunsolley JC. Comparison of debris extruded apically in straight canals: Conventional filing versus profile .04 Taper series 29. J Endod. 1998; 24(1): 18-22

19. Buldur B, Hascizmeci C, Aksoy S, Nur Aydin M, et al. Apical extrusion of debris in primary molar root canals using mechanical and manual systems. Eur J Paediatr Dent. 2018; 19(1): $16-20$.

20. Kherlakian D, Cunha RS, Ehrhardt IC, Zuolo ML, et al. Comparison of the incidence of postoperative pain after using 2 reciprocating systems and a continuous rotary system: A prospective randomized clinical trial. J Endod. 2016; 42(2): 171-6.

21. Nair PNR, Henry SP, Cano V, Vera J. Microbial status of apical root canal system of human mandibular first molars with primary apical periodontitis after "one-visit" endodontic treatment. Oral Surg, Oral Med, Oral Pathol, Oral Radiol Endodontol. 2005; 99(2): 231-52.

22. Ruiz-Hubard EE, Gutmann JL, Wagner MJ. A quantitative assessment of canal debris forced periapically during root canal instrumentation using two different techniques. J Endod. 1987; 13(12): 554-8

23. McKendry DJ. Comparison of balanced forces, endosonic, and step-back filing instrumentation techniques: quantification of extruded apical debris. J Endod. 1990; 16(1): 24-7.

24. Al-Omari MAO, Dummer PMH. Canal blockage and debris extrusion with eight preparation techniques. J Endod. 1995; 21(3): 154.

25. Reddy SA, Hicks ML. Apical extrusion of debris using two hand and two rotary instrumentation techniques. J Endod. 1998; 24(3): 180-3.

26. Del Fabbro M, Afrashtehfar KI, Corbella S, El-Kabbaney A, et al. In vivo and in vitro effectiveness of rotary nickel-titanium vs manual stainless steel instruments for root canal therapy: Systematic review and meta-analysis. J Evid Based Dent Pract. 2018; 18(1): 59-69.

27. Arias A, de la Macorra JC, Azabal M, Hidalgo JJ, et al. Prospective case controlled clinical study of post-endodontic pain after rotary root canal preparation performed by a single operator. J Dent. 2015;43(3):389-95.

28. Kashefinejad M, Harandi A, Eram S, Bijani A. Comparison of single visit post endodontic pain using Mtwo rotary and hand K-file instruments: A Randomized Clinical Trial. J Dent (Tehran). 2016; 13(1): 10-7.

29. Mollashahi NF, Saberi EA, Havaei SR, Sabeti M. Comparison of postoperative pain after root canal preparation with two reciprocating and rotary single-file systems: A randomized clinical trial. Ir Endod J. 2017; 12(1): 15-9.

30. Çiçek E, Koçak MM, Koçak S, Sag-lam BC, et al. Postoperative pain intensity after using different instrumentation techniques: a randomized clinical study. J Appl Oral Sci: revista FOB. 2017; 25(1): 20-6.

31. Gambarini G, Testarelli L, De Luca M, Milana V, et al. The influence of three different instrumentation techniques on the incidence of postoperative pain after endodontic treatment. Ann Stomatol (Roma). 2013; 4(1): 152-5.
32. Neelakantan P, Sharma S. Pain after single-visit root canal treatment with two single-file systems based on different kinematics - a prospective randomized multicenter clinical study. Clin Oral Investig. 2015; 19(9): 2211-7.

33. Relvas JBF, Bastos MMB, Marques AAF, Garrido ADB, et al. Assessment of postoperative pain after reciprocating or rotary $\mathrm{NiTi}$ instrumentation of root canals: A randomized, controlled clinical trial. Clin Oral Investig. 2016; 20(8): 1987-93.

34. Jain N, Pawar A, Gupta A. Incidence and severity of postoperative pain after canal instrumentation with reciprocating system, continuous rotary single file system, versus SAF system. Endod practice. 2016; 10: 153-60.

35. Sun C, Sun J, Tan M, Hu B, et al. Pain after root canal treatment with different instruments: A systematic review and meta-analysis. Oral Dis. 2018; 24(6): 908-19.

36. Robinson JP, Lumley PJ, Cooper PR, Grover LM, et al. Reciprocating root canal technique induces greater debris accumulation than a continuous rotary technique as assessed by 3-dimensional micro-computed tomography. J Endod. 2013; 39(8): 1067-70.

37. Alves FRF, Paiva PL, Marceliano-Alves MF, Cabreira LJ, et al. Bacteria and hard tissue debris extrusion and intracanal bacterial reduction promoted by XP-endo Shaper and Reciproc instruments. J Endod. 2018; 44(7): 1173-8.

38. Caviedes-Bucheli J, Castellanos F, Vasquez N, Ulate E, et al. The influence of two reciprocating single-file and two rotaryfile systems on the apical extrusion of debris and its biological relationship with symptomatic apical periodontitis. A systematic review and meta-analysis. Int Endod J. 2016; 49(3): 255-70.

39. Tinaz AC, Alacam T, Uzun O, Maden M, et al. The effect of disruption of apical constriction on periapical extrusion. J Endod. 2005; 31(7): 533-5.

40. Tanalp J, Kaptan F, Sert S, Kayahan B, et al. Quantitative evaluation of the amount of apically extruded debris using 3 different rotary instrumentation systems. Oral Surg, Oral Med, Oral Pathol, Oral Radiol, Endodontol. 2006; 101(2): 250-7.

41. Hargreaves K, Berman L, Rotstein I. Cohen's pathways of the pulp. Eleventh edition. ed: Mosby: Elsevier Health Sciences; 2015

42. Jain P. Current therapy in endodontics. Ames, lowa: Wiley Blackwell; 2016.

43. Webber J. Shaping canals with confidence: WaveOne GOLD single-file reciprocating system. Roots. 2015(1): 34-40.

44. Sattapan B, Nervo GJ, Palamara JEA, Messer HH. Defects in rotary nickel-titanium files after clinical use. J Endod. 2000; 26(3): 161-5.

45. Sotokawa T. An analysis of clinical breakage of root canal instruments. J Endod. 1988; 14(2): 75-82.

46. Sattapan B, Palamara JEA, Messer HH. Torque during canal instrumentation using rotary nickel-titanium files. J Endod. 2000; 26(3): 156-60.

47. Martín B, Zelada G, Varela P, Bahillo JG, et al. Factors influencing the fracture of nickel-titanium rotary instruments. Int Endod J. 2003; 36(4): 262-6.

48. Gabel WP, Hoen M, Steiman HR, Pink FE, et al. Effect of rotational speed on nickel-titanium file distortion. J Endod. 1999; 25(11): 752-4.

49. Pruett JP, Clement DJ, Carnes DL. Cyclic fatigue testing of nickel-titanium endodontic instruments. J Endod. 1997; 23(2): 77-85.

50. Plotino G, Grande NM, Melo MC, Bahia MG, et al. Cyclic fatigue of NiTi rotary instruments in a simulated apical abrupt curvature. Int Endod J. 2010; 43(3): 226-30.

51. Parashos $P$, Messer HH. Rotary NiTi instrument fracture and its consequences. J Endod. 2006; 32(11): 1031-43.

52. Tripi TR, Bonaccorso A, Condorelli GG. Cyclic fatigue of different nickel-titanium endodontic rotary instruments. Oral Surg, Oral Med, Oral Pathol, Oral Radiol, Endodont. 2006; 102(4): 106-14. 
53. Gambarini G, Grande NM, Plotino G, Somma F, et al. Fatigue resistance of engine-driven rotary nickel-titanium instruments produced by new manufacturing methods. J Endod. 2008; 34(8): $1003-5$

54. De-Deus G, Moreira EJL, Lopes HP, Elias CN. Extended cyclic fatigue life of F2 ProTaper instruments used in reciprocating movement. Int Endod J. 2010; 43(12): 1063-8.

55. You S-Y, Bae K-S, Baek S-H, Kum K-Y, et al. Lifespan of one nickel-titanium rotary file with reciprocating motion in curved root canals. J Endod. 2010; 36(12): 1991-4.

56. Gambarini G, Gergi R, Naaman A, Osta N, et al. Cyclic fatigue analysis of twisted file rotary NiTi instruments used in reciprocating motion. Int Endod J. 2012; 45(9): 802-6.

57. Jonker C, van der Vyver PJ. Reciprocating instruments in endodontics: A review of the literature. S Afr Dent J. 2014; 69(9): 404-9.

58. Webber J, Machtou P, Pertot W, Kuttler S, et al. The WaveOne single-file reciprocating system. Roots. 2011; 1: 28-33.

59. Gupta R, Tomer A, Rohilla S. Single file endodontics: Boon or myth? Asian Pacific J Health Sci. 2016; 3(2): 102-5.

60. Fidler A. Kinematics of 2 reciprocating endodontic motors: The difference between actual and set values. J Endod. 2014; 40(7): 990-4.

61. Bürklein S, Benten S, Schäfer E. Quantitative evaluation of apically extruded debris with different single-file systems: Reciproc, F360 and OneShape versus Mtwo. Int Endod J. 2014; 47(5): 405-9.

62. Bürklein S, Schäfer E. Apically extruded debris with reciprocating single-file and full-sequence rotary instrumentation systems. J Endod. 2012; 38(6): 850-2.

63. Toyoglu M, Altunbas D. Influence of different kinematics on apical extrusion of irrigant and debris during canal preparation using K3XF instruments. J Endod. 2017; 43(9): 1565-8.

64. Surakanti J, Venkata RC, Vemisetty H, Dandolu R, et al. Comparative evaluation of apically extruded debris during roo canal preparation using ProTaper, Hyflex and Waveone rotary systems. J Conserv Dent. 2014; 17(2): 129

65. Arslan H, Dog-anay E, Alsancak M, Çapar ID, et al. Comparison of apically extruded debris after root canal instrumentation using Reciproc instruments with various kinematics. Int Endod J. 2016; 49(3): 307-10.

66. Üstün Y, Çanakçi BC, Dinçer AN, Er O, et al. Evaluation of apically extruded debris associated with several $\mathrm{Ni}$-Ti systems. Int Endod J. 2015; 48(7): 701-4.

67. Dincer AN, Er O, Canakci BC. Evaluation of apically extruded debris during root canal retreatment with several NiTi systems. Int Endod J. 2015; 48(12): 1194-8.

68. Silva EJ, Carapiá MF, Lopes RM, Belladonna FG, et al. Comparison of apically extruded debris after large apical preparations by full-sequence rotary and single-file reciprocating systems. Int Endod J. 2016; 49(7): 700-5.

69. Ozsu D, Karatas E, Arslan H, Topcu M. Quantitative evaluation of apically extruded debris during root canal instrumentation with ProTaper Universal, ProTaper Next, WaveOne, and selfadjusting file systems. Eur J Dent. 2014; 8(4): 504-8.

70. Koçak S, Koçak MM, Sag-lam BC, Türker SA, et al. Apical extrusion of debris using self-adjusting file, reciprocating singlefile, and 2 rotary instrumentation systems. J Endod. 2013; 39(10): 1278-80.

71. Vivekanandhan P, Subbiya A, Mitthra S, Karthick A. Comparison of apical debris extrusion of two rotary systems and one reciprocating system. J Conserv Dent. 2016; 19(3): 245-9.

72. Kirchhoff AL, Fariniuk LF, Mello I. Apical extrusion of debris in flat-oval root canals after using different instrumentation systems. J Endod. 2015; 41(2): 237-41.

73. Uslu Gla, Özyürek T, Yılmaz K, Gündog-ar M, et al. Apically extruded debris during root canal instrumentation with Reciproc Blue, HyFlex EDM, and XP-endo Shaper nickel-titanium files. J Endod. 2018; 44(5): 856-9.
74. Salloum S, Torbey C, Bassam S, Dib C. Reciprocal and continuous rotation is two sides of the same coin. J Dent Health Oral Disord Ther. 2018; 9(3).

75. Flanders D. Endodontic patency. How to get it. How to keep it. Why it is so important. N Y State Dent J. 2002; 68: 30-2.

76. Hülsmann M, Schäfer E. Apical patency: Fact and fiction-a myth or a must? A contribution to the discussion. Endo. 2009; 3: 285-307.

77. Mounce RE, Glassman G. Principle driven cleaning, shaping and obturation in orthograde first-time endodontic treatment. Oral Health. 2010; 100(5): 40-9.

78. Paleker F, van der Vyver PJ. Glide path enlargement of mandibular molar canals by using K-files, the ProGlider File, and G-Files: A comparative study of the preparation times. J Endod. 2017; 43(4): 609-12.

79. American Association of Endodontists (AAE). Glossary of endodontic terms. $9^{\text {th }}$ ed: American Association of Endodontists; 2015.

80. Lambrianidis T, Tosounidou E, Tzoanopoulou M. The effect of maintaining apical patency on periapical extrusion. J Endod. 2001; 27(11): 696-8.

81. IzU KH, Thomas SJ, Zhang P, Izu AE, et al. Effectiveness of sodium hypochlorite in preventing inoculation of periapical tissues with contaminated patency files. J Endod. 2004; 30(2): 92-4.

82. Yaylali IE, Demirci GzK, Kurnaz S, Celik G, et al. Does maintaining apical patency during instrumentation increase postoperative pain or flare-up rate after nonsurgical root canal treatment? A systematic review of randomized controlled trials. J Endod. 2018; 44(8):1228-36.

83. Hartmann RC, Peters OA, de Figueiredo JAP, Rossi-Fedele G. Association of manual or engine-driven glide path preparation with canal centring and apical transportation: a systematic review. Int Endod J. 2018; 51(11): 1239-52.

84. West JD. The endodontic glidepath: "Secret to rotary safety". Dent Today. 2010; 29(9): 90-3.

85. Elnaghy AM, Elsaka SE. Evaluation of root canal transportation, centering ratio, and remaining dentin thickness associated with ProTaper Next instruments with and without glide path. J Endod. 2014; 40(12): 2053-6.

86. Rodrigues E, De-Deus G, Souza E, Silva EJ. Safe mechanical preparation with reciprocation movement without glide path creation: result from a pool of 673 root canals. Braz Dent J. 2016; 27(1): 22-7.

87. Patiño PV, Biedma BM, Liébana CR, Cantatore G, et al. The influence of a manual glide path on the separation rate of $\mathrm{NiTi}$ rotary instruments. J Endod. 2005; 31(2): 114-6.

88. Cassim I, van der Vyver PJ. The importance of glide path preparation in endodontics: a consideration of instruments and literature. S Afr Dent J. 2013; 68(7): 324-7.

89. Khatavkar R, SH. Importance of patency in endodontics. Endodontology. 2010; 22: 85-91.

90. Seltzer S, Naidorf IJ. Flare-ups in endodontics: I. Etiological factors. J Endod. 1985; 11(11): 472-8.

91. Topçuog-lu HS, Düzgün S, Akpek F, Topçuog-lu G, et al. Influence of a glide path on apical extrusion of debris during canal preparation using single-file systems in curved canals. Int Endod J. 2016; 49(6): 599-603.

92. Gunes B, Yeter Y. Effects of different glide path files on apical debris extrusion in curved root canals. J Endod. 2018; 44(7): 1191-4.

93. Basmadjian-Charles CL, Farge P, Bourgeois DM, Lebrun T. Factors influencing the long-term results of endodontic treatment: a review of the literature. Int Dent J. 2002; 52(2): 81-6.

94. Plotino G, Özyürek T, Grande NM, Gündog-ar M. Influence of size and taper of basic root canal preparation on root canal cleanliness: A scanning electron microscopy study. Int Endod J. 2019; 52(3): 343-51. 
95. Grande NM, Ahmed HMA, Cohen S, Bukiet F, et al. Current assessment of reciprocation in endodontic preparation: A comprehensive review - Part I: Historic perspectives and current applications. J Endod. 2015; 41(11): 1778-83.

96. Tinoco JM, De-Deus G, Tinoco EM, Saavedra F, et al. Apical extrusion of bacteria when using reciprocating single-file and rotary multifile instrumentation systems. Int Endod J. 2014; 47(6): 560-6.

97. Zupanc J, Vahdat-Pajouh N, Schäfer E. New thermomechanically treated NiTi alloys - a review. Int Endod J. 2018; 51(10): 1088-103.

98. Goo H-J, Kwak SW, Ha J-H, Pedullà E, et al. Mechanical properties of various heat-treated nickel-titanium rotary instruments. J Endod. 2017; 43(11): 1872-7.

99. Ha JH, De-Deus G, Versluis A, Kwak SW, et al. Safe pseudoelastic limit range under torsional loading with Reciproc Blue. Int Endod J. 2019; 52(2): 244-9.

100. You S-Y, Kim H-C, Bae K-S, Baek S-H, et al. Shaping ability of reciprocating motion in curved root canals: A comparative study with micro-computed tomography. J Endod. 2011; 37(9): 1296-300.

101. Varela-Patino P, Ibanez-Parraga A, Rivas-Mundina B, Cantatore $G$, et al. Alternating versus continuous rotation: A comparative study of the effect on instrument life. J Endod. 2010; 36(1): 157-9.

102. Yared G. Canal preparation using only one Ni-Ti rotary instrument: preliminary observations. Int Endod J. 2008; 41(4): 339-44.

103. Gavini G, Caldeira CL, Akisue E, Candeiro GTdM, et al. Resistance to flexural fatigue of reciproc R25 files under continuous rotation and reciprocating movement. $\mathrm{J}$ Endod. 2012; 38(5): 684-7.

104. Perez-Higueras JJ, Arias A, de la Macorra JC, Peters OA. Differences in cyclic fatigue resistance between ProTaper Next and ProTaper Universal instruments at different levels. sJ Endod. 2014; 40(9): 1477-81.

105. Paqué F, Zehnder M, De-Deus G. Microtomography-based comparison of reciprocating single-file F2 ProTaper technique versus rotary full sequence. J Endod. 2011; 37(10): 1394-7.

106. Espir CG, Nascimento-Mendes CA, Guerreiro-Tanomaru JM, Freire LG, et al. Counterclockwise or clockwise reciprocating motion for oval root canal preparation: A micro-CT analysis. Int Endod J. 2018; 51(5): 541-8.

107. Siddique R, Nivedhitha MS. Effectiveness of rotary and reciprocating systems on microbial reduction: A systematic review. J Conserv Dent. 2019; 22(2): 114-22.

108. Karatas E, Arslan H, Kırıcı D, Alsancak M, Çapar ID. Quantitative evaluation of apically extruded debris with Twisted File Adaptive instruments in straight root canals: Reciprocation with different angles, adaptive motion and continuous rotation. Int Endod J. 2016; 49(4): 382-5.

109. Arslan H, Doganay E, Alsancak M, Çapar ID, Karatas E, Gündüz HA. Comparison of apically extruded debris after root canal instrumentation using Reciproc instruments with various kinematics. Int Endod J. 2016; 49(3): 307-10.

110. Paqué F, Boessler C, Zehnder M. Accumulated hard tissue debris levels in mesial roots of mandibular molars after sequential irrigation steps. Int Endod J. 2011; 44(2)

111. Gizem Demiray K, Ahmet G, Bülent A, Güven K. Comparison of the smear layer- and debris-removal abilities and the effects on dentinal microhardness of $5 \%$ and $17 \%$ EDTA solutions used as final irrigants: In vitro study. Acta Odontol Turc. 2016; 33(2): 63-8.

112. Kim H-J, Park S-J, Park S-H, Hwang Y-C, et al. Efficacy of flowable gel-type EDTA at removing the smear layer and inorganic debris under manual dynamic activation. J Endod. 2013; 39(7): 910-4.

113. Gupta J, Nikhil V, Jha P. Corelation between machine-assisted endodontic irrigant agitation and apical extrusion of debris and irrigant: A laboratory study. Sci World J. 2014; 2014: 346184. DOI: $10.1155 / 2014 / 346184$
114. Baker NA, Eleazer PD, Averbach RE, Seltzer SP. Scanning electron microscopic study of the efficacy of various irrigating solutions. J Endod. 1975; 1(4): 127-35.

115. Hinrichs RE, Walker WA, $3^{\text {rd }}$, Schindler WG. A comparison of amounts of apically extruded debris using handpiece-driven nickel-titanium instrument systems. J Endod. 1998; 24(2): 102-6.

116. Ferraz CCR, Gomes NV, Gomes BPFA, Zaia AA, et al. Apical extrusion of debris and irrigants using two hand and three engine-driven instrumentation techniques. Int Endod J. 2001; 34(5): 354-8.

117. Myers GL, Montgomery S. A comparison of weights of debris extruded apically by conventional filing and canal master techniques. J Endod. 1991; 17(6): 275-9.

118. Johnson BR, Remeikis NA. Effective shelf-life of prepared sodium hypochlorite solution. J Endod. 1993; 19(1): 40-3.

119. Grossman LI, Meiman BW. Solution of pulp tissue by chemical agents. J Am Dent Assoc. 1941; 28(2): 223-5.

120. Buck RA, Eleazer PD, Staat RH, Scheetz JP. Effectiveness of three endodontic irrigants at various tubular depths in human dentin. J Endod. 2001; 27(3): 206-8.

121. Zehnder M. Root canal irrigants. J Endod. 2006; 32(5): 38998.

122. Violich D, Chandler N. The smear layer in endodontics - a review. Int Endod J. 2010; 43: 2-15.

123. Putzer P, Hoy L, Günay $H$. Highly concentrated EDTA gel improves cleaning efficiency of root canal preparation in vitro. Clin Oral Investig. 2008; 12(4): 319-24.

124. Cruz A, Vera J, Gascón G, Palafox-Sánchez CA, et al. Debris remaining in the apical third of root canals after chemomechanical preparation by using sodium hypochlorite and glyde: An in vivo study. J Endod. 2014; 40(9): 1419-23.

125. De-Deus G, Marins J, de Almeida Neves A, Reis C, et al. Assessing accumulated hard-tissue debris using micro-computed tomography and free software for image processing and analysis. J Endod. 2014; 40(2): 271-6. 